\title{
RELATIVELY SAFE TREATMENTS (PARTIAL / COMPLETE COVERAGE SPRAY) FOR THE CONTROL OF SCOLYTUS AMYGDALI (COLEOPTERA: SCOLYTIDAE) IN APRICOT ORCHARDS IN EGYPT
}

\author{
HASHIM, S. M., A. W. TADROS and R. M. ABDEL-MOATY \\ Plant Protection Research Institute, Agric. Res. Center, MOA, Giza, Egypt.
}

(Manuscript received 22 February 2018)

\begin{abstract}
A new relatively safe and commercial partial / complete coverage spray to control Scolytus amygdali (Coleoptera: Scolytidae) in apricot orchard (applied only twice instead of 6 current MOA recommended chemical treatments / season) at ElKattatba district, (Menofia Governorate). Percentages reduction of infestation for the following 7 applications for one year treatment (2015), two successive years (2015 and 2016), and three successive years (2015, 2016 and 2017) were, respectively, as follow: A: Horticultural treatments: 1) dormant winter pruning (27.73 increased to 34.87 then $38.88 \%), 2$ ) summer pruning (15.06 increased to 17.65 then $19.24 \%), 3$ ) dormant and summer pruning (34.06 increased to 39.50 then $45.69 \%$ ). B: Chemical treatment: 4) MOA recommended chemical treatments (3 treatments during spring and 3 treatments during autumn) (80.57 increased to 85.08 then $89.58 \%)$,5) new commercial partial / complete coverage chemical treatments ( 1 treatment during spring and 1 treatment during autumn) (61.35 increased to 71.01 then $79.16 \%$ ). Third: Horticultural (winter and summer pruning as an additive control) together with chemical treatments: 6) pruning together with MOA recommended treatments resulted in $86.03 \%$ increased to $88.24 \%$ then $96.39 \%$, and 7) pruning together with new partial / complete coverage treatment resulted in $68.78 \%$ increased to $78.15 \%$ then $91.78 \%$. The new commercial and relatively safe partial / complete coverage chemical control eliminates the pesticide use ( 2 treatments insteat of 6 ) and reduces residues, prevent the outbreaks of secondary species, decrease the environmental pollution, encourage the role of the biological control agents and obtain better production of decontamination of fruits through using limited insecticides.
\end{abstract}

\section{INTRODUCTION}

Scolytus amygdali (Coleoptera: Scolytidae) is a serious and destructive insect boring pest in apricot orchards of Egypt. Beetles are active from February to December and bore oviposition entrance and exit holes. Larvae are active all the year round and bore their feeding tunnels under the bark of the stem and branches, causing weakness and quick death of tree branches. It has 5-6 annual generations each year. 
This continuous expanded period of beetles activity (10 months), needs very expensive chemical control with at least 6 complete coverage spray treatments ( 3 in spring and 3 in autumn, as MOA recommendation). Recommendations for the control of $S$. amygdali infestation in apricot orchards are still mainly directed towards the chemical control treatments. Excessive use of chemical insecticides is very expensive, has adverse effect on the biological control agents (parasites, predators, and pathogens), and increase environmental pollution.

Apricot is a profitable crop, and spread allover the new reclaimed lands in addition to old Delta lands. This study is a pioneer attempt to control the bark beetle S. amygdali with low coast and relatively more save complete coverage spray treatment in addition to horticultural control factors.

S. amygdali was studied biologically (Tadros, 1994), and ecologically (Tadros and Abd-Allah, 1987; and Tadros, et al., 2006) to determine of the proper timing of control treatments. Chemical control trials for S. amygdali were carried out by BenYehuda and Mendel (1997) in Israel. Ben Yehuda (2002) also found that application of non-selective insecticides; burning of dead trees and pruning slash were environmentally unsafe and were often ineffective control.

The aim of the present investigation was to prevent the yield losses due to $S$. amygdali borer, eliminate the pesticide use and residues, prevent the outbreaks of secondary species, decrease the environmental pollution, magnify the role of the biological control agents and obtain better production of decontamination of fruits through using limited insecticides by partially complete coverage spray treatments.

\section{MATERIALS AND METHODS}

Experiments were carried out at El-Kattatba district, Cairo / Alexandria High Way (Menofia Governorate), in an apricot orchard (10 feddans and 20 years old) highly infested with $S$. amygdali. Trials were extended during 3 successive years from January 2015 to December 2017. The following 8 treatments were evaluated using completely randomized design (one feddan each treatment and each treatment was replicated 3 times).

1. Dormant pruning treatment (Horticultural treatments): During January of each year, the regular horticultural winter pruning was carried out including the infested branches (characterized with exit holes).

2. Summer pruning treatment (Horticultural treatments): During July, the newly infested branches were pruned.

3. Dormant and summer pruning treatments (Horticultural treatments):

Treatments numbers 1 and 2 were applied together. 
4. spraying treatment (recommended chemical treatments): The MOA recommended insecticides, Phenthoate 50\% EC (Cidial L) each at the rate of 200 cc / 100 I. w. was sprayed alternatively 3 times in spring season at 2 week interval on the $2^{\text {nd }}$ week of March after flower set, $4^{\text {th }}$ week of March and $2^{\text {nd }}$ week of April, then spraying was stopped at least one month before harvesting. During autumn season 3 sprays were also applied at monthly intervals ( $1^{\text {st }}$ week of September, $3^{\text {rd }}$ week of September and $1^{\text {st }}$ week of October). Spraying was practiced by a motor tank (600 liters of water) with high volume sprayer (boom nozzle) and mainly directed towards the stem and branches.

5. Spraying with Dormant and summer pruning treatments (Horticultural and recommended chemical treatments): Treatments numbers 3 and 4 were applied together.

6. New Partial / complete coverage spray treatments (chemical treatments): The MOA recommended insecticides, Phenthoate 50\% EC (Cidial $\mathrm{L}, \mathrm{PHI}$ is 21 days), and Chloropyriphos (Dorsban, PHI is 21 days) at the rate of $200 \mathrm{cc} / 100$ I. w., and Labda-Cyhalothrin 2.5\% EC (Dolf, PHI is 14 days) at the rate of $100 \mathrm{cc} / 100 \mathrm{I}$. w. were sprayed alternatively in spring and autumn seasons in the same number, dates and spraying equipment mentioned in item 4 . The new technique is to spray one row of trees with one of the 3 and leave the adjacent two rows, thus spraying $1 / 3$ of the orchard, i.e., one treatment in spring and one treatment in autumn (two treatments each year instead of six).

7. Partial / complete coverage spray with Dormant and summer pruning treatments (Horticultural and new chemical treatments): Treatments numbers 4 and 6 were applied together.

8. Untreated Check treatment: Check trees were left untreated as control treatment.

The previous 8 treatments were conducted from January 2014 to December 2015 season. During the $2^{\text {nd }}$ season (January 2015 to December 2016), the same previous 8 treatments were carried out on the same past year trees to evaluate the cumulative effect of the two successive years (from January 2014 to December 2016). During the $3^{\text {rd }}$ season (January 2016 to December 2017), the same previous 8 treatments were carried out on the same past year trees to evaluate the cumulative effect of the three successive years (from January 2014 to December 2017). Treatments were evaluated by counting the newly emerged beetles indicated by the newly exit holes on one meter long branches scattered on 10 trees "replicates" during the following season. New exit holes were continuously counted and canceled by painting after each year treatment. 
The efficiency of treatments was based on the percentage reduction of infestation (Henderson and Tilton, 1955), as follow:

$\%$ reduction of infestation $=[(\mathrm{C}-\mathrm{T}) / \mathrm{C}] 100$

Where, $\mathrm{C}$ : the mean number of new exit holes in untreated trees.

$\mathrm{T}$ : the mean number of new exit holes in treated trees.

Grouping of treatments was based on ANOVA test and "Least Significant Difference" (Snedecor and Cochran, 1990).

\section{RESULTS AND DISCUSSION}

A new commercial and more safe mean of chemical control of Scolytus amygdali (Coleoptera: Scolytidae) by partial / complete coverage spray applied in an apricot orchard at El-Kattatba district (Menofia Governorate) during three successive years (2015, 2016 and 2017). Horticultural, MOA recommended chemical treatments and new partial / complete spraying treatment. The respective rates reductions of infestation with 7 control treatments applied for one year, and two and three successive years.

The direct effects of the 7 treatments (infestation reductions rates) were evaluated when applied for only one single year (2015). The cumulative effects (rates reductions of infestation) were also evaluated as well for two successive years (2015 and 2016) and three successive years (2015, 2016 and 2017).

A. Effect of one single year treatment (Direct effect): (Table, 1)

1. Effect of dormant pruning (horticultural treatments alone): Winter pruning treatment during January 2014 was of considerable value since S. amygdali severely attack the branches, which mainly included in the dormant pruning as well as the stem of trees. The reduction of infestation with a mean of $27.73 \%$.

2. Effect of summer pruning (horticultural treatments alone): Because infestation with $S$. amygdali expanded almost all the year round, summer pruning of newly infested branches was of some value as the percentage reduction in the borer infestation with a mean of $15.06 \%$.

3. Effect of chemical spraying treatment (according to MOA recommendation): Alternative treatments with the MOA recommended insecticide, Phenthoate $50 \%$ EC (Cidial L) at the rate of $200 \mathrm{cc} / 100 \mathrm{I}$. w. (2 weeks interval) 3 times in spring season and 3 times in autumn season reduced $S$. amygdali infestation with a mean of $80.57 \%$.

4. New Partial / complete coverage chemical spray treatments (new chemical treatments): Sequence treatments with MOA recommended insecticides, Diazinon 60\% EC (Basudin), Phenthoate 50\% EC (Cidial L), and Labda-Cyhalothrin 2.5\% EC (Dolf) each at the rate of $300 \mathrm{cc} / 100 \mathrm{I}$. w. (3 week interval) 3 times in spring season and 3 times in autumn season with Diazinon, 
Phenthoate, and Chloropyriphos (Dorsban) reduced S. amygdali infestation with a mean of $61.35 \%$.

5. Effect of combined dormant and summer pruning treatments (horticultural treatments alone): Remarkable degree of $S$. amygdali infestation was achieved when dormant and summer pruning treatments were applied together. The increased percentages reduction of the borer infestation with a mean of $34.06 \%$.

6. Effect of combined MOA spraying with Dormant and summer pruning treatments (horticultural and recommended chemical treatments): Excellent results were achieved when these combined treatments were applied together showing a mean of $\mathbf{8 6 . 0 3 \%}$ reductions of infestation. The effect was due to all the three treatments rather than one main treatment. This treatment hindered the beetle settings, the beetle oviposition, hatching and larval entry inside the apricot wood.

7. Effect of combined New spraying with Dormant and summer pruning treatments (horticultural and recommended chemical treatments): Excellent results were achieved when these combined treatments were applied together showing a mean of $68.78 \%$ reductions of infestation. The effect was due to all the three treatments rather than one main treatment. This treatment hindered the beetle settings, the beetle oviposition, hatching and larval entry inside the apricot wood.

Table 1. Effect of one single year, two and three successive treatments on the percentage reduction in $S$. amygdali infestation in apricot orchards at Menofia governorate during 2015, 2016 and 2017 seasons.

\begin{tabular}{|c|c|c|c|c|c|c|}
\hline \multirow{3}{*}{ Treatments } & \multicolumn{6}{|c|}{$\%$ reduction of infestation } \\
\hline & \multicolumn{2}{|c|}{$\begin{array}{l}1 \text { year } \\
\text { treatment } \\
(2015)\end{array}$} & \multicolumn{2}{|c|}{$\begin{array}{c}2 \text { years } \\
\text { treatments } \\
(2015 \& 2016) \\
\end{array}$} & \multicolumn{2}{|c|}{$\begin{array}{c}3 \text { years } \\
\text { treatments } \\
(2015-2017) \\
\end{array}$} \\
\hline & $\begin{array}{l}\text { Mean } \\
\text { No. of } \\
\text { exit } \\
\text { holes }\end{array}$ & $\%$ & $\begin{array}{l}\text { Mean } \\
\text { No. of } \\
\text { exit } \\
\text { holes }\end{array}$ & $\%$ & $\begin{array}{l}\text { Mean } \\
\text { No. of } \\
\text { exit } \\
\text { holes }\end{array}$ & $\%$ \\
\hline $\begin{array}{ll}\text { A: } & \text { Horticultural Treatments: } \\
1 . & \text { Dormant pruning } \\
2 . & \text { Summer pruning } \\
\text { 3. } & \text { Dormant \& summer pruning }\end{array}$ & $\begin{array}{l}331 \\
389 \\
302\end{array}$ & $\begin{array}{l}27.73 \\
15.06 \\
34.06\end{array}$ & $\begin{array}{l}310 \\
392 \\
288\end{array}$ & $\begin{array}{l}34.87 \\
17.65 \\
39.50\end{array}$ & $\begin{array}{l}305 \\
403 \\
271\end{array}$ & $\begin{array}{l}38.88 \\
19.24 \\
45.69\end{array}$ \\
\hline $\begin{array}{l}\text { B: Chemical Treatments: } \\
\text { 4. } \quad \text { MOA treatment } \\
\text { 5. } \quad \text { NEW treatment }\end{array}$ & $\begin{array}{c}89 \\
177\end{array}$ & $\begin{array}{l}80.57 \\
61.35\end{array}$ & $\begin{array}{c}71 \\
138\end{array}$ & $\begin{array}{l}85.08 \\
71.01\end{array}$ & $\begin{array}{c}52 \\
104\end{array}$ & $\begin{array}{l}89.58 \\
79.16\end{array}$ \\
\hline $\begin{array}{l}\text { C: } \text { Combined Treatments: } \\
\text { 6. } \quad \text { Treatments, } 3+4 \\
\text { 7. } \quad \text { Treatments, } 3+5\end{array}$ & $\begin{array}{c}64 \\
143\end{array}$ & $\begin{array}{l}86.03 \\
68.78\end{array}$ & $\begin{array}{c}56 \\
104\end{array}$ & $\begin{array}{l}88.24 \\
78.15\end{array}$ & $\begin{array}{l}18 \\
41\end{array}$ & $\begin{array}{l}96.39 \\
91.78\end{array}$ \\
\hline $\begin{array}{l}\text { D: Untreated Treatments: } \\
8 . \quad \text { Check }\end{array}$ & 458 & -- & 476 & -- & 499 & -- \\
\hline
\end{tabular}




\section{B. Effect of two and three successive year treatments (Cumulative effect):}

1. Effect of successive horticultural treatments: As shown in Table (1), dormant pruning treatment alone in winter somewhat reduced $S$. amygdali infestation when applied for two successive years (34.87\%). However, continuous winter pruning effectively shared in reducing the borer infestation resulting in $38.88 \%$ after three successive years. Summer pruning had less effect (17.65\% and $19.24 \%)$ on the reduction of infestation although it was repeated for two and three successive years, respectively. However, applying dormant and summer pruning treatments together for two and three successive years effectively reduced infestation $(39.50 \%$ and $45.69 \%$, respectively). Dormant and summer pruning somewhat shared in the reduction of infestation and should be included in the integrated control program.

2. Effect of successive chemical treatments: Table (1) showed that repeated chemical spraying treatments (according to MOA recommendation) for two and three successive year's highly reduced S. amygdali infestation $(85.08 \%$ and $89.58 \%$, respectively). However, applying new partial / complete coverage chemical spray treatments for two and three successive years effectively reduced infestation with $71.01 \%$ and $79.16 \%$, respectively.

3. Effect of successive horticultural together combined with chemical treatments: Table (1) finally concluded that repeating horticultural together with MOA recommended chemical spraying treatments for two and three successive years highly reduced S. amygdali infestation (88.24\% and $96.39 \%$, respectively). On the other hand, repeating horticultural together with new partial / complete coverage chemical spray treatments for two and three successive years also effectively reduced infestation showing $78.15 \%$ and $91.78 \%$, respectively in addition to commercial and safe factors.

Table 2. Differences in the percentage reduction of $S$. amygdali infestation between one, two and three year's successive treatments in apricot orchards at Menofia governorate during 2015, 2016 and 2017 seasons.

\begin{tabular}{|c|c|c|c|c|c|c|}
\hline \multirow{2}{*}{\multicolumn{2}{|c|}{ Treatments }} & \multicolumn{5}{|c|}{$\%$ reduction of infestation } \\
\hline & & $\begin{array}{c}1 \text { year } \\
\text { treatment } \\
(2015)\end{array}$ & $\begin{array}{c}2 \text { years } \\
\text { treatments } \\
(2015 \& \\
2016)\end{array}$ & $\begin{array}{c}\% \\
\text { differen } \\
\text { ces }\end{array}$ & $\begin{array}{c}3 \text { years } \\
\text { treatments } \\
(2015- \\
2017)\end{array}$ & $\begin{array}{c}\% \\
\text { differenc } \\
\text { es }\end{array}$ \\
\hline \multicolumn{7}{|c|}{ A: Horticultural Treatments: } \\
\hline 9. & Dormant pruning & 27.73 & 34.87 & 7.14 & 38.88 & 11.15 \\
\hline 10. & Summer pruning & 15.06 & 17.65 & 2.59 & 19.24 & 4.18 \\
\hline 11. & Dormant \& summer pruning & 34.06 & 39.50 & 5.44 & 45.69 & 11.63 \\
\hline \multicolumn{7}{|c|}{ B: Chemical Treatments: } \\
\hline 12. & MOA treatment & 80.57 & 85.08 & 4.51 & 89.58 & 9.01 \\
\hline 13. & New treatment & 61.35 & 71.01 & 9.66 & 79.16 & 17.81 \\
\hline \multicolumn{7}{|c|}{ C: Combined Treatments: } \\
\hline 14. & Treatments, $3+4$ & 86.03 & 88.24 & 2.21 & 96.39 & 10.36 \\
\hline 15. & Treatments, $3+5$ & 68.78 & 78.15 & 9.37 & 91.78 & 23.00 \\
\hline
\end{tabular}




\section{Cumulative differences due the effect of two and three successive year treatments:}

\section{Differences due the effect of successive horticultural treatments: As} shown in Table (2), repeating winter pruning treatment alone for two successive years increased reduction of $S$. amygdali infestation with $7.14 \%$, and $11.15 \%$ after three successive years, respectively. Very low reduction of $S$. amygdali infestation (2.59\% and $4.18 \%$ ) were achieved when summer pruning was repeated for two and three successive years, respectively. Repeating winter and summer pruning treatments together for two and three successive years increased reduction of $S$. amygdali infestation with $5.44 \%$, and $11.63 \%$ after three successive years, respectively. Repeating dormant and summer pruning somewhat shared in the reduction of infestation and should be included in the integrated control program.

2. Differences due the effect of successive chemical treatments: Table (1) showed that repeated chemical spraying treatments (according to MOA recommendation) for two and three successive year's reduced $S$. amygdali infestation only with $4.51 \%$ and $9.01 \%$, respectively. However, repeating new partial / complete coverage chemical spray treatments for two and three successive years effectively reduced infestation with considerable percent ( $9.66 \%$ and $17.81 \%$, respectively).

c. Differences due the effect of successive horticultural and chemical treatments: As shown in Table (2), repeating winter, summer pruning with chemical treatments according to MOA recommendation together for two successive years increased reduction of S. amygdali infestation with $2.21 \%$, and $10.36 \%$, respectively. Very high differences increase in the reduction of $S$. amygdali infestation $(9.37 \%$ and $23.00 \%)$ were achieved when winter and summer pruning with new partial / complete coverage chemical spray treatments were repeated for two and three successive years, respectively. This Very high difference increase in the reduction of $S$. amygdali infestation (23.00\%) was due to preservation of biological control agents.

D. Statistical analysis: Statistical analysis and grouping of the 7 treatments applied for one, two and three years concluded that there were significant differences between treatments and classified as: \{insignificant differences between the same letters of grouping\}

\section{a. Superior group (more than 80 - 100\%):}

1. Pruning and MOA treatments for three years $(96.39 \%) \mathrm{A}$

2. Pruning and new treatments for three years $(91.78 \%) \mathrm{A}$

3. MOA treatments for three years (89.58\%) A

4. Pruning and MOA treatments for two years $(88.24 \%) A$

5. Pruning and MOA treatments for one year (86.03\%) A 
6. MOA treatments for two years $(85.08 \%) \mathrm{A}$

7. MOA treatments for one year (80.57\%) AB

\section{b. Sufficient group ( 60 - less than $80 \%$ ):}

1. NEW treatments for three years $(79.16 \%) \mathrm{B}$

2. Pruning and new treatments for two years $(78.15 \%) \mathrm{B}$

3. New treatments for two years $(71.01 \%) B$

4. Pruning and new treatments for one year $(68.78 \%) \mathrm{B}$

5- New treatments for one year (61.35\%) BC

\section{c. Moderate group (30 - less than $60 \%$ ):}

1. Pruning (winter and summer) for three years (45.69\%) D

2. Pruning (winter and summer) for two years (39.50\%) D

3. Winter pruning for three years $(38.88 \%) \mathrm{D}$

5. Winter pruning for two years $(34.87 \%) \mathrm{DE}$

5. Winter pruning for one year (34.06\%) DE

\section{d. Less group (less than $\mathbf{3 0 \%}$ ):}

1. Winter pruning for one year (27.73\%) E

2. Summer pruning for three years $(19.24 \%) \mathrm{F}$

3. Summer pruning for two years $(17.65 \%) \mathrm{F}$

5. Summer pruning for one year (15.06\%) $\mathrm{F}$

\section{E. Discussion:}

From the foregoing results in Tables (1) and (2), it could be concluded that the direct effect of one single year treatments on $S$. amygdali infestation varied from one treatment to another. The cumulative effect of two successive year treatments concluded that the infestation could be highly reduced if these treatments repeated year after another. The effect of horticultural treatments alone (winter and summer pruning together) approximated $34.1,39.5$ and $45.7 \%$ reduction of infestation when applied for 1, 2 and 3 years, respectively. However, the majority of the effect was due to dormant winter pruning (27.7, 34.9 and $38.9 \%$, respectively). Summer pruning was negligible (15.1, 17.7 and $19.2 \%$, respectively).

Chemical treatments according to MOA recommendations (6 treatments / year) were effective in the reduction of the borers' infestation (80.6, 85.1 and 89.6\%) when applied for one, two and three successive years, respectively.

New chemical partial / complete coverage treatments ( 2 treatments / year) were also effective in the reduction of the borers' infestation (61.4, 71 and 79.2\%) when applied for one, two and three successive years, respectively.

Pruning in winter and summer pruning, together with recommended MOA chemical treatments magnified the reduction of infestation (86\%) and greatly 
magnified the reduction of infestation when applied for two and three successive years (88.2 and $96.4 \%)$, respectively.

Pruning in winter and summer pruning, together with new chemical treatments magnified the reduction of infestation (68.8\%) and greatly magnified the reduction of infestation when applied for two and three successive years (78.2 and 91.8\%), respectively.

Combining horticultural and chemical treatments and repeating these treatments from one year to another were of great value in effective control.

Repeating winter and summer pruning together with recommended MOA chemical treatments increased the reduction of infestation with $10.4 \%$ after three successive years, while this increase was $23 \%$ after three successive years when the new chemical treatments were applied.

It could be concluded that the regular practices and environmentally safe treatments (pruning) in addition to commercial and low contaminated chemical treatment (new partial / complete coverage spray) year after another very highly increased the reduction of $S$. amygdali infestation and in the meantime environmentally safe (less chemical contamination, preserve the biological control agents), save money and crop production.

The previous new chemical treatments on the control of $S$. amygdali are applied for the first time in apricot orchards in Egypt. However, Ben-Yehuda and Mendel (1997) and Ben Yehuda (2002) in Israel found that applications of nonselective insecticides, burning of dead trees and pruning slash were environmentally unsafe and were often ineffective for S. amygdali control.

In China, Li et al. (1995) and Wang et al. (1998) stated that S. seulensis was a pest of stone fruits, causing $15-30 \%$ damage to apricot trees. They proposed enforcing quarantine and improving orchard management as control measures, while spraying insecticides resulted in $>85 \%$ control.

\section{REFERENCES}

1. Ben-Yehuda, S. and Z. Mendel. 1997. Control of wood boring beetles (Capnodis spp. and Scolytus spp.) in deciduous orchards in Israel. Alon-Hanotea, 51(4): 170-172.

2. Ben Yehuda, S.; T. Tolasch; W. Francke; R. Gries; G. Gries; D. Dunkelblum; Z. Mendel; P. Witzgall; B. Mazomenos and M. Konstantopoulou. 2002. Aggregation pheromone of the almond bark beetle Scolytus amygdali (Coleoptera: Scolytidae). IOBC-WPRS Working Group 'Use of Pheromones and Other Semiochemicals in Integrated Control'. Pheromones and other boil. tech. for 
insect control in orchards and vineyards. Proc. of working group meeting, Samos, Greece, Sep. 25-29, 2000. Bull. OILB-SROP, 25(9): 259-269.

3. Henderson, C.F. and E.W. Tilton. 1955. Test with acaricides against the brown wheat mite. J. Econ. Entomol., 48: 157-161.

4. Snedecor, W and A. Cochran. 1990. Statistical Methods. The Iowa State Univ. press, Ames, Iowa, USA.

5. Tadros, A. W. 1994. The life-cycle of the shot-hole bark beetle, Scolytus amygdali Guer. (Coleoptera: Scolytidae) on peach in Egypt. Egypt. J. Agric. Res., 72 (3): 699-705. [5 $5^{\text {th }}$ Professional Fruit Workers Conf., Ashville, North Carolina, USA, Oct. $17-18,1990,5$ (15)].

6. Tadros, A.W., A. M. Abdel-Rahman and I. A. Abdel-Hamid. 2006. Stone Fruit Tree Pests: (5) Monitoring the major apricot tree borers (Ptosima undecimmaculata, Chlorophorus varius, Macrotoma palmata, and Scolytus amygdali) in Egypt. Egypt. J. Agric. Res., Egypt, accepted, 19 ${ }^{\text {th }}$ February 2006.

7. Tadros, A. W.; and F. F. Abd-Allah. 1987. The seasonal fluctuation in the population density of the shot-hole bark beetle, Scolytus amygdale Guer. (Coleoptera: Scolytidae) on apricot in Egypt. $12^{\text {th }}$ Interna. Cong. for Statistics, Computer Sci., Social and Demo. Res., Ain-Shams Univ. (28 ${ }^{\text {th }}$ March-2 ${ }^{\text {nd }}$ April 1987), Cairo, Egypt: pp 391-400. 


\section{Scolytus amygdali معاملات آمنة لمكافحة خنافس قلف الحلويات بالرش الجزئي / الكلي في حدائق المشمش في مصر (COL.: SCOLYTIDAE)}

صلاح محروس هاشم ، انطون ولسن تادرس و راضي محمدي عبد المعطي

معهد بحوث وقاية النباتات- مركز البحوث الزراعية- وزارة الزراعة- الدقي - الجيزة- مصر

تم تقييم فعالية طريقة جديدة آمنة نسبيا و إقتصادية إلي حد كبير لككافحة خنافس قلف الحلويات COLEOPTERA: SCOLYTIDAE) S. amygdali) بالرش الجزئي / الكلي (مرتان فقط خلال الموسم بدلا من 7 مرات) في حدائق المشم في مصر في منطقة الخطاطبة، محافظة

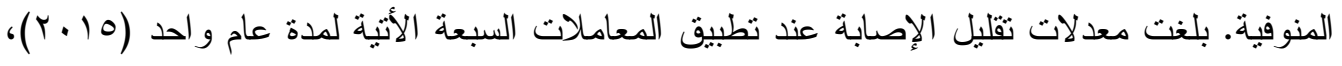

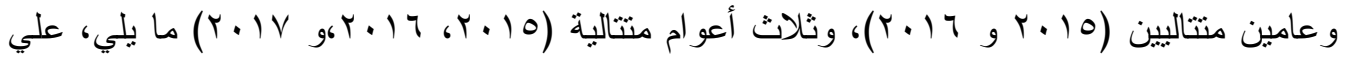

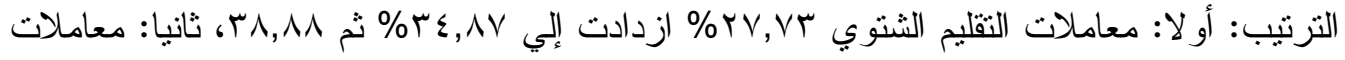

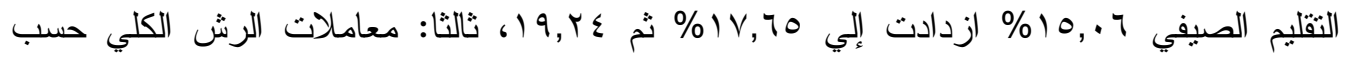

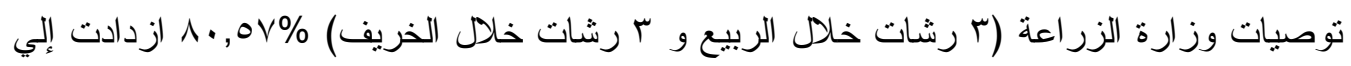

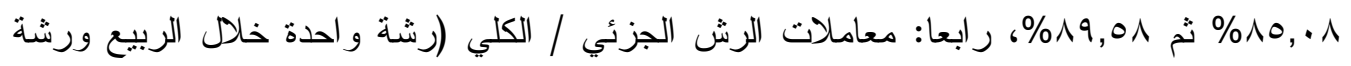

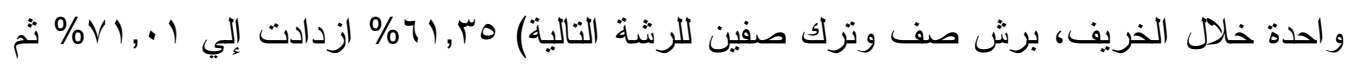

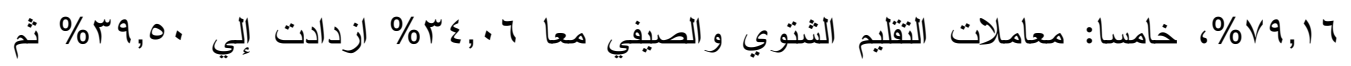

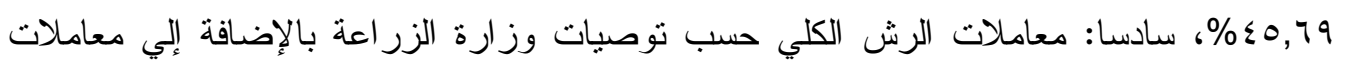

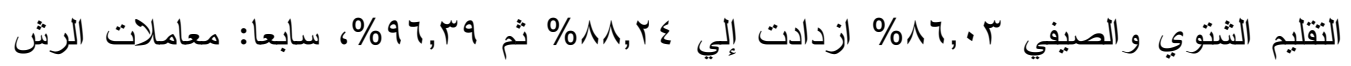

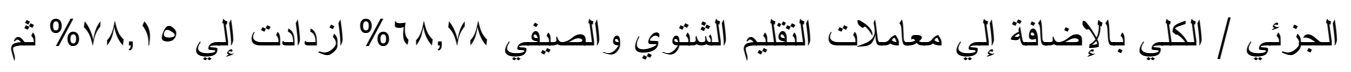

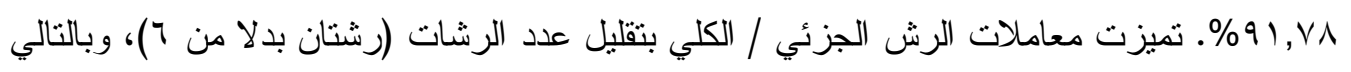

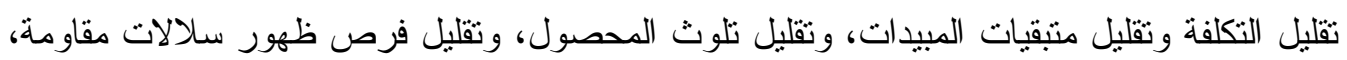
وتقليل فرص حدوث فور انات لأفات أخري منل المن و الأكاروس، وتنقليل تلوث البيئة، وتعظيم دور

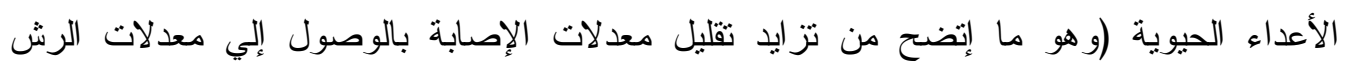
التقلبدي عند تكر ار المعاملة لعدة سنوات. 
